\title{
Patient in Europa : opzoek naar een Europees geneeskundig dienstverleningsrecht
}

Citation for published version (APA):

Nys, H. (2000). Patient in Europa : opzoek naar een Europees geneeskundig dienstverleningsrecht. Maastricht University. https://doi.org/10.26481/spe.20001201hn

Document status and date:

Published: 01/12/2000

DOI:

10.26481/spe.20001201hn

Document Version:

Publisher's PDF, also known as Version of record

\section{Please check the document version of this publication:}

- A submitted manuscript is the version of the article upon submission and before peer-review. There can be important differences between the submitted version and the official published version of record.

People interested in the research are advised to contact the author for the final version of the publication, or visit the DOI to the publisher's website.

- The final author version and the galley proof are versions of the publication after peer review.

- The final published version features the final layout of the paper including the volume, issue and page numbers.

Link to publication

\footnotetext{
General rights rights.

- You may freely distribute the URL identifying the publication in the public portal. please follow below link for the End User Agreement:

www.umlib.nl/taverne-license

Take down policy

If you believe that this document breaches copyright please contact us at:

repository@maastrichtuniversity.nl

providing details and we will investigate your claim.
}

Copyright and moral rights for the publications made accessible in the public portal are retained by the authors and/or other copyright owners and it is a condition of accessing publications that users recognise and abide by the legal requirements associated with these

- Users may download and print one copy of any publication from the public portal for the purpose of private study or research.

- You may not further distribute the material or use it for any profit-making activity or commercial gain

If the publication is distributed under the terms of Article $25 \mathrm{fa}$ of the Dutch Copyright Act, indicated by the "Taverne" license above, 
PATIËNT IN EUROPA op zoek naar een Europees geneeskundig dienstverleningsrecht 
d. Nys, Masstricht 2000

1SBN 9052782954

Uniwersitaire Pers Mastricht

Vomgeving en druk: Datawyse Maastricht bv 


\section{PATIËNT IN EUROPA op zoek naar een}

Europees geneeskundig dienstverleningsrecht

Rede uitgesproken bil de aanvaarding van het ambt van hoogleraar in het internationaal gezondheidsrecht aan de Universiteit Maastricht op vrijdag 1 december 2000 door Herman Nys 


\section{INHOUD}

Patiẻnt in Europa 7

Europees geneeskundig dienstverleningsrecht 8

Gemeenschappelijke beginselen van het Europees

geneeskundig dienstverleningsrecht

Hoe "cultuurgebonden" is het geneeskundig

dienstverleningrecht?

Autonomie "à la française" en "à l'américaine"

Rechtsvergelijkend onderzoek

Besluit en dankwoord 


\author{
Geachte Rector, \\ Leden van de Universitaire Gemeenschap, \\ Geachte Collegae, \\ Dames en Heren,
}

\title{
PATIENT IN EUROPA
}

Een burger uit een EU-lidstaat die zich voor geneeskundige hulp naar een andere lidstaat van de EU wil begeven, moet dat ongehinderd kunnen doen. Het Hof van Justitie heeft zich in de lerse abortuszaak op 4 oktober 1991 in deze zin uitgesproken. ${ }^{1}$ De nationale wetgever mag bepaalde geneeskundige handelingen verbieden of aan voorwarden onderwerpen, maar mag niet verhinderen dat een onderdaan zich naar een andere lidstaat begeeft om daar een dergelijke handeling te ondergaan. Ook mag de terugbetaling van de kosten verbonden aan een geneeskundige behandeling ondergaan in een andere lidstaat niet afhankelijk worden gesteld van een toestemming door het bevoegde verzekeringsorgaan. ${ }^{2}$

Toch komt het vandaag de dag niet vaak voor dat iemand welbewust op zoek gaat naar geneeskundige hulp over de eigen landsgrens. De problemen die hij moet trotseren blijven niet gering. Vaak zal hij zich moeten kunnen uitdrukken in een taal die de zijne niet is. De verplaatsing, het verblijf en de geneeskundige hulp kunnen veel tijd en geld kosten. Bij die praktische moeilijkheden komt de confrontatie met vreemd recht: in beginsel is het recht van het land van vestiging van de dienstverlener van toepassing. ${ }^{3}$ Wie zich desondanks toch over de grens waagt, heeft daar vaak dwingende redenen voor: het lerse abortusverbod in de zaak Grogan; het ontbreken van iedere artsenkeuze in de zaak Kohll (er werkte slechts éen orthodontist in het Groot Hertogdom Luxemburg); het wettelijk verbod een post mortem inseminatie te laten toepassen in het Verenigd Koninkrijk als de toestemming van de overleden partner niet vast staat, in de zaak-Blood. ${ }^{4}$

1 H.w. J. 4 oktober 1991, Society for the protection of unborn children Ireland t.Grogan, Jur. $1-4685$.

2 H.x., 28 april 1998, Decker t. Câisse de Maladle des employés privés, Jur.1-1831; Kohll t. Union des Caisses de Maladie, finr I- 1931.

3 LOOS M.B.M., "Naar een Europees denstverleningsrecht", N./.H., 2000, 452.

4 R.y Human Fertilisation and Embryology Authorites, ex parte Blood (1997) 2 All ER 687, Court of Appeal. 
Ook valt in de nabife toekomst geen grote toename te verwachten wan patiênten die welbewust geneeskundige hulp over de grens gaan zoeken. Als de kennis van de Engelse taall in brede lagen van de bevolking van de EU-lidstaten blijft toenemen, zal taal wellicht een minder belangrijke rem worden. Inschakeling van tolken en vertaalcomputers kan er ook toe bijdragen dat patiënten sneller de weg naar een andere lidstaat vinden. Daar staat tegenover dat telegeneeskunde of "geneeskunde op afstand" en telechirurgie zouden kunnen leiden tot nog minder grensoverschrijding door patie̋nten. Maar het effect daarvan mag zeker niet worden overdreven. In het Witboek van Jacques Delors (Naar de $21^{\text {ste }}$ eeuw: wegen en uitdagingen) klonk het (achteraf bezien) overdreven optimistisch dat "tegen het jaar 2000 multimediale verbindingen tot stand moeten worden gebracht tussen de grote oncologische centra, de beenmergbanken en de belangrijkste sociale zekerheidsinstellingen". Veel is daarvan vandaag niet te merken.

Kortom, afgezien van de grensstreken zal het zelden voorkomen dat iemand bewust op zoek gaat naar geneeskundige hulp over de grens. Doet hij dat toch, dan neemt hij het vreemd recht er graag bij: in de Ierse abortuszaak en de zaak- Blood was dat een stuk aantrekkelijker dan het lerse resp. het Engelse recht.

\section{EUROPEES GENEESKUNDIG DIENSTVERLENINGSRECHT}

Heeft een Europees geneeskundig dienstverleningsrecht dan enige zin? Bedoeld zijn gemeenschappelijke basisbeginselen die in de EU-lidstaten ten grondslag liggen aan de rechtsregels in verband met het verstrekken van geneeskundige diensten aan patiënten. ${ }^{6}$ De kern van dit geneeskundig dienstverleningsrecht wordt gevormd door de rechtsregels die beogen de rechten van de patiènt te beschermen en te versterken. Er zijn daarnaast nog andere relevante regels zoals deze met betrekking tot de beroepsuitoefening. Die laat ik hier verder buiten beschouwing.

Het hoofdargument voor een Europees geneeskundig dienstverleningsrecht is de gelijkheid wan behandeling van de Europese burger. Alle Europese burgers worden van voor hun geboorte tot na hun overlijden recht-

5 geelteerd door DOMMERS I.," Europese integratie en wolksgezondheid; handel noopt tot handelen" in ROSCAM ABBING H.D.C., en VAN BERKESTIN Th. Gezowaheidsbeleid in Europa, Bohn ${ }_{i}$ Houten, $1995_{k} 43$.

6 Vergelijk BOELE-WOLLKI K, "De weg naar een Europees fandilerecht" FIR, 1997,2. 
streeks en soms diep ingrijpend geraakt door de rechtsregels die de geneeskundige dienstverlening regelen. Gaat het op de duur nog wel op dat deze regels van land tot land grondig verschillen? ${ }^{7}$ Waarom moet een patiënt in Portugal vrede nemen met een minder geinformeerde toestemming dan een patiënt in Zweden? Waarom moet een patiënt in Belgie enke» worden ingelicht over de zogenaamde normale en voorzienbare risico's terwijl een patiënt in Frankrijk het recht heeft over leder ernstig risico te worden ingelicht, ook al doet het zich maar zelden voor? Waarom geniet een wilsonbekwame patiënt in Duitsland een betere bescherming dan een Griekse willsonbekwame patiënt? Ik ben er meer en meer van overtuigd geraakt dat deze verschillen vaak minder verband houden met principes dan met casuïstisch gegroeide benaderingen en onwetendheid omtrent de relevante rechtsontwikkelingen in andere lidstaten. De tijd is aangebroken om op een systematische wijze de verschillen in de rechtsbescherming van patiënten in Europa te inventariseren en te evalueren in het licht van de gelijkheid van behandeling. Het bevorderen van de eenduidigheid in de toepassing van patièntenrechten is wel geen in het EG-verdrag neergelegd officieel beleidsdoel, maar vloeit well min of meer onvermijdelijk uit het geheel van EG-regelgeving voort, aldus Legemaate ${ }^{8}$.

Bovendien zal de groeiende mobiliteit van burgers binnen Europa op de duur van onderuit de roep versterken naar grotere gelijkheid inzake de bescherming van de rechten van de patiênt. Een Duitse Erasmus student die in Rome studeert en daar geneeskundige verzorging nodig heeft, zal niet goed begrijpen waarom hij in Duitsland wel het recht heeft om volledig te worden geïnformeerd over de risico's verbonden aan een behandeling, maar niet in Italië. Hetzelfde onbegrip zal te beluisteren zijn bij een Nederlandse bejaarde chronisch zieke die overwintert in het Spaanse zuiden; bi j een Zweeds kaderlid die enkele jaren in Portugal doorbrengt in opdracht van zijn multinationale werkgever en bij de Belgische toerist die tijdens een vakantie in Griekenland medische hulp nodig heeft. Allemaal zullen ze hun ervaringen en hun verwachtingen inzake het beschermingsniveau als patient met zich nemen. Dat zal natuurlijk niet vanzelf leiden tot grotere gelijkheid wat betreft de rechtsbescherming van

7 wergelijk voor het Huropees familierecht $\$$ TEENHOF G., "Op weg nat een lisurope familerecht" in ANTOKOLSKAIA M.V. era, Een zoektocht mar Europess famileredu, Deventer, Kluwer: 1999, 10.

8 LEGEMAATE I. "Gezondheidsbeleid" in ROSCAM ABBING M.D.C. BW WAN MERKESTIIN" Th., o.c. 179 . 
patieinten. De kans is zelfs groot dat de student, het kaderlid en de toerist zo enigszins mogelijk zich naar het eigen land haasten om daar de geneeskundige zorg te krijgen die ze nodig hebben. En de bejaarde patiënt zal aan de Spaanse zuidkust wel een arts van Nederlandse origine vinden die hem hellpt overeenkomstig de vertrouwde vaderlandse standaard. Maar dit ogenschijnlijke tegenargument versterkt naar mijn mening nog het gelijke behandelingsargument: hebben de Italianen, Spanjaarden, Portugezen en Grieken in eigen land dan niet recht op een gelijke bescherming van hun rechten als patiënt als Duitsers, Nederlanders, Zweden en Belgen in hun land hebben?

Daar komt nog bij dat het woor chronische patienten vaak niet zo eenvoudig zal zijn om naar het thuisland terug te keren. Terwijl juist deze patiënten zich veel meer bewust zịn van hun rechtspositie en een veel actievere rol vervullen in de arts-patiëntrelatie dan patiënten die maar voor korte tijd deze rol moeten opnemen. Dikwijls zijn chronische patiënten ook hechter georganiseerd in zelfhulpgroepen of andere patiëntenverenigingen, meer en meer ook in Europees verband. Zij hebben al een jarenlange ervaring in belangenverdediging. Verdraagt onze beeldvorming van een kortstondige en zeer van zijn hulpverleners afhankelijke patiënt zich nog niet goed met het beeld van een aktieve consument van gezondheidszorg, bij chronische patiënten hebben we daar in het algemeen al veel minder moeite mee. Anders dan wat voor patiẻntenbescherming geldt, is consumentenbescherming als zodanig wel uitdrukkelijk doel van de EU (artikel 153 EG-Verdrag). Deze vaststelling is van groot belang voor het bepleiten van een minimaal niveau aan gelijke rechtsbescherming van patiënten in Europa. Zeker vanuit het perspectief van de chronische patiënten bekeken, beantwoordt de eenduidigheid in de toepassing van patiëntenrechten in Europa aan een groeiende behoefte. Vooral deze patiënten zullen hun verwachtingen en ervaringen inzake de bescherming van hun rechten als patiënt en consument van zorg uitdragen naar andere lidstaten. Daar hoeft zelfs geen groeiende mobiliteit aan te pas te komen. Bij wijze van voorbeeld verwijs ik naar naar de ethical code die in 1996 werd opgesteld door de European Alliance of Genetic Support Groups. ${ }^{9}$ Deze alliantie is een Europese koepelorganisatie van Europese en nationale verenigingen van patiënten die lijden aan genetische aandoe-

9 tekst opgenomen in NYS H, en TROUET C., Codex Medical Law. International Encydopaedia of Medical Law, Kluwer, the Hagnie, 1999, II.B.2.1-143. 
ningen. In dit document wordt gepleit voor gelijke behandeling inzake het recht op informatie, het handhaven van de vertrouwelijkheid en de vrijheid van keuze inzake te nemen beslissingen. Een ander voorbeeld dat het Europese kader zelfs overstijgt, zijn de richtlijnen woor het predictief testen voor de ziekte van Huntington die werden opgesteld door de International Huntington Association samen met de World Federation on Neurology (Research Group on Huntington's Chorea). ${ }^{10}$

Het laatste voorbeeld verduidelijkt clat de druk om tot een grotere gelijkheid van behandeling te komen niet enkel uitgaat van patiěnten. Patiènten hebben recht op geneeskundige hulpverlening van goede kwaliteit in overeenstemming met de aanvaarde professionele standaard waar zij zich ook bevinden in de EU. ${ }^{11}$ Deze standaard kan verschillen vertonen tussen de lidstaten om rekening te houden met ondermeer culturele verschillen, maar die afwijkingen mogen niet van die aard zijn dat zij leiden tot suboptimale zorg. ${ }^{12}$ Een "europeanisering" van de zorgvuldigheidsnorm komt daarmee in het beeld. Europese verenigingen van zorgverleners zullen onder druk komen staan om via gemeenschappelijke standaarden te grote verschillen tussen de lidstaten tegen te gaan. Voor een concreet voorbeeld in dit verband verwijs ik naar een discussiedocument clat werd opgesteld in het kader van het Standing Committee of European Doctors over informed consent (april 2000). In dit document wordt uitdrukkelijk de vraag gesteld of "bearing in mind cultural differences which will determine approaches to this subject, delegations can agree on a minimum set of common principles to form the basis of a statement?".

Bij dit alles komt tenslotte nog dat te grote onderlinge verschillen tussen de nationale wetgevingen binnen een Europa zonder grenzen een ernstige belemmering vormen om tot een daadwerkelijke Europese identiteit te geraken. De economische en politieke integratie zal uiteindelijk ook een integratie of althans een behoorlijke mate van afstemming van het geneeskundig dienstverleningsrecht noodzakelijk maken. Het is onafwendbaar dat dit recht in de loop der jaren meer uniformiteit gaat vertonen. ${ }^{13}$ Zover zijn we nu nog niet. Laat ons eerst eens nagaan of er al al sprake is van gemeenschappelijke basisbeginselen.

10 zie de tekst in idem, 1.B. 1.V.1.-1-9.

11 SEGEST E. "Consumer protection and the free movement of medical practitioners in the European Union" European foumal of Heallin Law, 1997, 268.

12 ROSCAM ABBING H.D.C. "The right of the patlent to quality of medical practlice and the position of migrant doctors within the EU", Enoropean fowmal of Health Law, 1997, 358 . 


\section{GEMEENSCHAPPELUKE BECINSELEN VAN HET EUROPEES GENEESKUNDIG DIENSTVERLENINGSRECHT}

Nederlandse pleitbezorgers woor een Europees familie- en personenrecht hebben mij veel inspiratie bezorgd. Zij leggen er de nadruk op dat wooral de internationale mensentechtenverdragen er toe leiden dat personen-en familierechtelijke regels van landen, die deze verdragen respecteren, in toenemende mate gemeenschappelijke trekjes gaan vertonen. Dat is niet verbazingwekkend omdat dit gedeelte van het recht vele onderwerpen regelt, die in zeer nauw verband staan met de menselijke waardigheid en de persoonlijke integriteit. ${ }^{14}$ Ook in de bescherming van patièntenrechten staan beide beginselen centraal. Waar beoefenaars van het familierecht het verdragsrechtelijk Europees famillerecht nog bij elkaar moeten sprokkelen ${ }^{15}$ is mijn opdracht in dit opzicht wat gemakkelijker. Sedert 1.997 bestaat in het kader wan de Raad van Europa het Europees verdrag tot bescherming van de rechten van de mens en de waardigheid van het menselijk wezen bij de toepassing van de biogeneeskunde. Deze laatste uitdrukking kan tot misverstanden leiden. Zij verwijst naar genetica, (xeno-)transplantatie, klonen, reproductieve geneeskunde, medischwetenschappelijk onderzoek en andere technische hoogstandjes. Geheel in overeenstemming met deze opgeroepen verwachtingen bevat het Verdrag bepalingen over het menselijk genoom (hoofdstuk 4, artikel 11 tot 14), het wetenschappelijk onderzoek (hoofdstuk 5, artikel 15 tot 18), de wegneming van organen en weefsels bij levende donoren (hoofdstuk 6 , artikel 19 en 20 ). Het eerste aanvullend protocol bij het Verdrag bevat een kloneringsverbod. Het Verdrag beoogt het individu te beschermen tegen verkeerde aanwendingen van de wetenschappelijke vooruitgang. Maar dat is niet de enige bekommernis van dit Verdrag. Uit de toelichting bij het Verdrag blijkt duidelijk dat de bescherming van mensen rechten en menselijke waardigheid niet alleen de hoog-technische (developing) gebieden van de geneeskunde beoogt maar ook de dagdagelijkse (longstanding) gezondheidszorg. ${ }^{16}$ Zo bekeken beschermt het Verdrag ook de rechten van de patiënt in de alledaagse geneeskundige hulpverlening. Het Verdrag is een waar patiêntenrechtenverdrag en "een mijlpaal op internationaal vlak in

13 STEENHOY G., o.c., 10

14 DE GROOT G.R. "Op weg natreen turopees personen- en familierecht?", A.A, 1995, 29.

1.5 zite het overzicht bil DE HONDT W.A., "Verdragsrechtelifk europees familierecht" in ANTOKOLSRAIA MV $v_{i}, a_{2}, a c$.

1.6 Explanatory Memorandum, $\$ 7$. 
de bescherming van de rechtspositie van de patient". ${ }^{17}$ Alle kernrechten van de patiênt komen in lhet Verdrag ter sprake met name het recht op informed consent (hoofdstuk $2_{i n}$ artikelen 5-9); het recht op eerbied voor het privélleven en bescherming van geneeskundige persoonsgegevens (hoofdstuk 3, artikel 10); het recht op medische dienstwerliening overeenkomstig de professionele standaard (hoofdstuk 1 , artikel 4); het recht op gelijke toegang tot gezondheidszorg (hoofdstuk 1 , artikel 3); het recht op rechtsbescherming ingeval inbreuk wordt gemaakt op de genoemde materiële rechten (hoofdstuk 8 , artikel 23 ) en het recht op vergoeding van ongeoorloofde schade (hoofdstuk 8 , artikel 24 ). In een aantal lidstaten van de Raad van Europa waaronder België heeft het Verdrag een krachtige impuls gegeven aan de voorbereiding van een wettelijke bescherming van de patiëntenrechten.

Ook nog in het kader van de Raad van Europa kunnen gemeenschappelijke beginselen van een Europees geneeskundig dienstverleningsrecht worden gevonden in de rechtspraak van het $\mathbb{1}$ uropees Hof over de naleving van het EVRM, in het bijzonder art. 8. Volgens sommigen is dat zelfs "het krachtigste instrument ter bescherming van de rechten van de patiẻnt". ${ }^{18}$

Evengoed als voor het personen-en familierecht, ${ }^{19}$ is de invloed van de EU op het geneeskundig dienstverleningsrecht daarentegen zo goed als nihil. Het grensoverschrijdend verkeer van hulpverleners (geregeld in meerdere richtlijnen) en van patiënten laat de bevoegdheid van de lidstaten om de geneeskundige dienstverlening te regelen onaangetast. De richtlijn van het Europees Parlement en de Raad van 24 oktober 1995 betreffende de bescherming van natuurlijke personen in verband met de behandeling van persoonsgegevens en betreffende het vrij verkeer van gegevens, regelt het recht van de patiënt om kennis te nemen (inzage) van zijn persoonsgegevens met betrekking tot zijn gezondheid maar laat de lidstaten ruimte om dit recht op een onrechtstreekse wijze te implementeren en dus minder verder te gaan in de geboden bescherming. ${ }^{20}$ Dat voorspelt weinig goeds voor een gemeenschappelijk Europees geneeskundig dienstverleningsrecht. Enkele jaren geleden was, na het mislukken

17 ROSCAM ABBING H.D.C. "Een Europese catalogus voor rechten wan de patient", Tihdshrift wor Gezondhetistecht, 1994, 314 .

18 LEGEMAATE $\pi_{1}, 0, \ldots, 179$.

19 DE GROOT G.R., o.c. 30.

20 LEGEMAATE J, $10, C, 190$. 
van een algemene richtlinn inzake de aansprakelijkheid voor gebrekkige diensten sprake van een specifieke richtlijn inzake de aansprakelijkheid voor geneeskundige diensten. Tot nog toe is die richtlijn er niet. Overigens kan men zich afvragen of het wel een goede zaak zou zijn de aansprakelijkheid voor geneeskundige diensten te harmoniseren zonder dat minstens tegelijk de verstrekking wan dergelijke diensten en in het bijzonder de bescherming van de rechten van de patiënt worden geharmoniseerd.

Maar er zijn ook tekenen die meer optimistisch stemmen. Het recente EU Handvest van fundamentele mensenrechten is zo'n signaal. Daarin zijn ook patiëntenrechten opgenomen. Artikel 3 legt de verplichting op om in het kader wan de geneeskunde en de biologie de vrije en voorgelichte toestemming van de betrokken persoon te respecteren. Artikel 21 verbiedt iedere vorm van discriminatie op basis wan onder andere genetische eigenschappen of handicap. Het Hof van Justitie van zijn kant heeft artikel 8 EVRM zo uitgelegd dat eenieder het recht heeft om te beslissen of medische informatie over hem al dan niet mag worden verzameld. ${ }^{21} \mathrm{Het}$ hof velde dit arrest op conclusie van de A.G. van Gerven die stelde: "het beginsel van medisch recht volgens welk voor elke medische handeling (behandeling, onderzoek, test of experiment) de geinformeerde toestemming van de betrokkene vereist is, lijkt algemeen te zijn aanvaard in het medisch recht van de lidstaten". ${ }^{22}$ Bij de voorbereiding van de richtlijn van het Europees Parlement en de Raad van 6 juli 1998 betreffende de rechtsbescherming van biotechnologische uitvindingen heeft het Europees Parlement vergeefs getracht om de eis wan informed consent en zeggenschap met betrekking tot het gebruik van lichaamsmateriaal in deze richtlijn te laten opnemen. Dat neemt niet weg dat dank zij deze discussie de gevoeligheid voor het thema patiẻntenrechten in het Europees Parlement sterk is toegenomen. Dat blijkt ook uit de besprekingen met het oog op de aanneming van een richtlijn van het Europees Parlement en de Raad betreffende de onderlinge aanpassing van de wettelijke en bestuursrechtelijke bepalingen wan de lidstaten inzake de toepassing van goede klinische praktijken bij de uitvoering van klinische proeven met geneesmiddelen voor menselijk gebruik. ${ }^{23}$ Dat juist op dit domein wordt gestreefd naar een onderlinge aanpassing van de nationale bepalingen zal misschien verba-

21 HW, 5 oktober $1994, \times$ Commisston of the European Communities fur. $=4737$.

22 VAN GIsRVEN W., Conclusies bil HV], 5 oktober 1994, VI. T.Gez, 1994,95,134.

23 zie voor de meest recente versie PB 20 oktober $2000, \mathrm{C} 300,32-44$. 
zing wekken. De nationale regelingen inzake de bescherming van proefpersonen vertonen nogal wat onderlinge verschillen hetgeen de bescherming van de proefpersonen niet ten goede komt. Langs de andere kant is inzake de harmonisering van die bescherming reeds een lange weg afgelegd. Sinds 1990 is een richtsnoer goede klinische praktijken voor klinische proeven met geneesmiddelen in de Europese Gemeenschap van kracht dat werd uitgevaardigd door een in het kader van de Europese Commissie opgerichte werkgroep. Dit Europese richtsnoer werd in 1997 vervangen door een internationaal richtsnoer voor goede kinische praktijken bij de uitvoering van klinische proeven met geneesmiddelen dat tot stand kwam in het kader van een driepartijenoverleg (International Conference on Harmonisation) tussen de EU, Japan en de Verenigde Staten van Amerika. De drijvende kracht achter beide richtsnoeren is de farmaceutische industrie zelf geweest. Het adequat functioneren van de Europese interne markt was de primaire drijfweer. Het streven naar een gelijke behandeling van de proefpersonen kwam sliechts op de tweede plaats maar dat neemt niet weg dat in de praktijk de rechtsbescherming van deze proefpersonen daadwerkelijk werd versterkt. Een en ander laat ook zijn sporen na inzake de rechten van de patiënt, al het maar omdat veel proefpersonen tevens patiënt zijn.

\section{HOE "CULTUURGEBONDEN" IS HET GENEESKUNDIG DIENSTVERLENINGRECHT?}

Het volstaat niet vast te stellen dat op Europees vlak gemeenschappelijke beginselen bestaan die de harde kern uitmaken van een geneeskundig dienstverleningsrecht om te mogen besluiten dat aan de toenemende behoefte van patiënten om in hun rechten op gelijke wijze te worden beschermd, is tegemoet gekomen. Die harde kern is voornamelijk verdragsrechtelijk van aard. Daardoor beschikken de lidstaten van de Europese Unie over nog heel wat ruimte voor variaties op nationaal vlak. Indien zou blijken dat deze nationale verschillen groot zijn, dan bestaat de gemeenschappelijkheid slechts op papier. Er zullen dan ingrijpender maatregelen nodig zijn om daadwerkelijke eenduidigheid te bekomen. Van de kaad van Europa kan niet veel meer worden verwacht. De EU zal dan het voortouw moeten nemen. Om deze reden is het van groot bellang inzicht te verwerven in de wijze waarop in de lidstaten van de EU deze gemeenschappelijke beginselen in de praktijk worden toegepast om zo de punten 
van overéenkomst en van onderscheid op te sporen. Vervolgens zullen vooral de punten van onderscheid nauwkeurig moeten worden bestudeerd om uit te maken of zij al dan niet van principiële aard zijn. Daarmee hangt samen het zoeken naar verklatingen voor deze werschillen.

In dit verband moet men zich hoeden voor te snelle besluiten. Neem het informed consent beginsel dat volgens van Gerven als algemeen beginsel van medisch recht aanvaard is in alle lidstaten van de EU. Literatuur $^{24}$ leert ons dat in de noordelijke en angelsaksische landen het individu steeds moet worden ingelicht terwijl in de mediterane landen veelal de tamillie wordt geinformeerd, niet de patiënt zelf. Informed consent mag dan als beginsel algemeen aanvaard zijn, onder invloed van allerlei elementen die ik gemakshalve even samenbreng onder de noemer "cultuur" wordt dit beginsel zo verschillend ingevuld dat men zich afvraagt of het een gemeenschappelijke verworvenheid kan worden genoemd. Zoals ook voorstanders van het Europees familierecht betogen, moet met dat cultuurargument toch voorzichtig worden omgegaan. Ongetwilfeld zijn er in het gezondheidsrecht een aantal heikele thema's zoals abortus en euthanasie waarover de opvattingen tussen de lidstaten (maar ook binnen de lidstaten) zo ver uit elkaar liggen omwille van religieuse, filosofische, ethische, juridische en andere redenen dat er zelfs niet aan moet worden gedacht om te komen tot een gemeenschappelijke Europese regeling. De auteurs van het Europees Verdrag Mensenrechten en Biogeneeskunde hebben dat ook begrepen en bewust deze thema's niet willen opnemen in het Verdrag. ${ }^{25}$ Niettemin moeten verschillen in cultuur ook niet overdreven worden. Vooreerst omdat cultuur geen statisch gegeven is, maar een dynamisch. Een mooie illustratie is een recente ontwikkeling in de medische plichtenleer van de Belgische Orde van geneesheren. Artikel 33 van de code van medische plichtenleer bevatte tot 14 april 2000 een aansporing voor artsen om een "noodlottige prognose" niet aan de patiënt zelf mee te delen maar aan de naastbestaanden. Sedert deze recente wijziging bepaalt dat artikel dat behoudens toepassing van de therapeutische exceptle en het recht om niet te weten, de patiènt altijd op de hoogte moet worden gebracht van een "fatale prognose". Over de tamilie wordt zelfs niet meer gesproken. Is België in noordelijke richting verschoven? Neen,

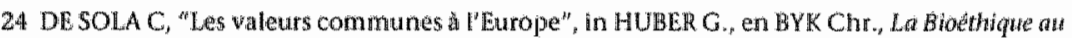
pluriel, Paris, John Libbey "1996" 106.

25. ROSCAM ABBING H.D.C. "Human rights and medicine. A Council of Europe Convention", Ruropean Journal of Health Law, $1996,201$. 
de cultuur (de medische deontologie) heeft zich aangepast an gewijzigde maatschappelijke opvattingen. Pogingen in het Belgische Parlement om euthanasie onder wel bepaalde voorwaarden wettelijk toe te laten zijn daar uiteraard niet vreemd aan. Bij dergelijke aanpassingen - en ik kom bij een tweede reden waarom voorzichtig met eigen-cultuur moet worden omgegaan - kan de rechtswetenschap een actieve rol spelen. Het recht moet een bijdrage leveren aan het bestrijden van schendingen wan fundamentele mensenrechten die worden gepleegd met eeuwenoude gebruiken als alibi. of men daarbij zover moet gaan als Steenhof schrijvend over het familierecht stelt, is betwistbaar: "Het familierecht heeft geen specifieke zending (meer) als hoeder van levensbeschouwelijke waarden, al dan niet verpakt als nationale cultuur of als rechtscultuur" ${ }^{26}$ Men kan zich toch maar moeilijk een Europees familierecht en een geneeskundig dienstverleningsrecht indenken dat niet op waarden is georiënteerd. ${ }^{27} \mathrm{lk}$ denk dan aan waarden als zelfbeschikking en confidentialiteit.

Nog een goede reden om voorzichtig om te springen met verwijzingen naar historisch gegroeide opvattingen is dat zij nogal eens subjectieve of toch moeilijk te controleren verklaringen voor bepaalde verschillen kunnen inhouden. Buj één van de meest bekende hedendaagse rechtsvergelijkers, Basil Markesinis vond ik het volgende voorbeeld. In eén van zijn artikelen $^{28}$ suggereert hij dat Duitse rechters zoveel hogere eisen stellen aan de informatieplicht over risico's verbonden aan een ingreep dan in de VS "with the National Socialist nightmare at the back of their minds". Dat de Duitse samenleving in het algemeen en het Duitse recht in het bijzonder zich ook vandaag de dag in hun houding inzake wetenschappelijk onderzoek met embryo's, wetenschappelijk onderzoek met wilsonbekwamen en euthanasie doorslaggevend laten inspireren door dat verleden is algemeen geweten en wordt door niemand ernstig betwist. Dat de strenge houding van de Duitse rechtspraak inzake het meedelen van witerst zeldzame en uiterst kleine risico's ook zou zijn ingegeven door die ervaringen is, denk ik veel minder geweten. Helaas laat Markesinis na zijn suggestie nader toe te lichten. Geheel overtuigend vind ik ze niet en ze verdient in leder geval nader te worden onderzocht. Dit is geen louter

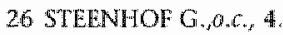

27 WORTMAN S.F.M., "Kroniek van het personen. en famillerecht", NMB, 2000, 1588 in een reactie op Steenhof.

28 MARKESIMIs B. "Comparative law - A subject in search of an audience", The Modem Law Review, 1990, 1.21 
academische kwestie. Samen met de zware bewijslast die op de Duitse arts rust - allweer een belangrijk verschilpunt tussen de lidstaten betreffende de toepassing van het gemeenschappelijk beginsel informed consent - heeft die informatieplicht geleid tot weing patièntvriendelijke "horror" - cattalogi die aan de patiënt ter ondertekening worden voorgelegd. Zoekend naar een op grotere gelijkheid gerichte invulling van het informed consent-vereiste in Europa kan men zich voorstellen dat de lat op dit punt een stuk lager zou dienen te worden gelegd. Maar wanneer de verklaring die Markesinis geeft juist is, dan zal het veel moeilijker vallen om dat te realiseren dan wanneer de verklaring in andere, meer oppervlakkige of toevallige elementen moet worden gezocht. Alleen door dit punt verder uit te diepen door gebruik te maken van originele Duitse bronnen (rechtspraak en rechtsleer) en door gesprekken met Duitse deskundigen inzake het geneeskundig dienstverleningstecht kan worden gepoogd een bevredigende verklaring te geven.

\section{AUTONOMIE "À LA FRANÇAISE" EN "À L'AMÉRICAINE"}

Ook elders dan in Duitsland wordt de culturele eigenheid graag benadrukt, ondermeer in Frankrijk. In haar conclusies naar aanleiding van een vordering die werd behandeld woor het administratief hof wan beroep van Parijs maakte de commissaire du gouvernement Heers een uitgebreide analyse van het recht van de patiênt in Frankrijk om een levensreddende behandeling te weigeren. ${ }^{29}$ Het hof diende zich uit te spreken over thet verzoek tot schadevergoeding ingediend door de familie van een overleden getuige van Jehova resp. een dergelijke getuige wegens het toedienen van bloed tegen de uitdrukkelijke en door de artsen gekende wil in van de betrokken getuigen van Jehovah. In haar conclusies doet Heers haar uiterste best om aan te tonen dat de ook naar haar zeggen in Europa onmiskenbare ontwikkeling naar de erkenning van patiëntenrechten "se concrétise dans des solutions juridiques différentes selon les traditions juridiques nationales". Het beginsel van de autonomie van de patiënt is in Franrijk zelfs neergelegd in de grondwettelijk beschermde individuele vrijheld. Maar Heers zet de verschillen tussen wat ze noemt "l'autonomie à la

29 HEERS M." "Responsabilte medicale et transfusion sanguine contre la volonté du patient; conclusions sur cour administrative dappel de Paris, 9 juin 1998 (2 especes) ${ }^{n}$. RFD admm, 1998, 6, 1231-1242. 
française" en de "autonomie anglo-saxonne" dik in de verf. Ook laat zij niet na op te merken dat de besprekingen over het Europees Verdrag Mensenrechten en Biogeneeskunde niet hebben geleid tot een consensus over alle problemen - wie had het anders verwacht? - en dat het Europees Hof voor de Rechten van de Mens een belangrijke interpretatiemarge aan de lidstaten laat over vraagstukken waaromtrent de nationale opvattingen uiteenlopen. Autonomie op zijn angelsaksisch is het recht op privacy, om alleen te worden gelaten en een zelfs levensredidende handeling te weigeren. De Franse autonomie-opvatting is "beaucoup plus étroit". Autonomie betekent de bekwaamheid om tegenover anderen en tegenover zichzelf universele plichten op te nemen. Een autonoom wezen kan ratio neel geen gedraging stellen die niet "universalisable" is. Een hongerstaker die eten weigert, een patiënt die een levensreddende behandeling weigert, is niet autonoom en dit rechtvaardigt het ingrijpen van de staat resp. de arts. De verplichting van een arts jegens zijn patiënt houdt niet op bij het respecteren van de wil van de patiënt. Zeker, wanneer er geen dreigend gevaar (danger imminent) is voor het leven van de patiënt, moet de wil van de patiënt worden gerespecteerd. Weliswaar is volgens artikel $16-3$ Code Civil (dat pas in 1994 in de Code werd gevoegd, na de aangeklaagde feiten) steeds toestemming nodig van de patiënt voor een medische behandeling maar volgens Heers mag dat artikel niet worden gelicht uit het geheel van juridische regels die het geneeskundig handelen beheersen. Uit dat geheel van juridische regels volgt dat "l'activité médicale est au service de la vie". De opdracht van een arts wordt niet (alleen) bepaald door het geneeskundig contract en de wil van partijen maar ook door het objectief recht. Daartoe behoren de onbeschikbaarheid (indisponibilité) en onschendbaarheid (inviolabilité) van het menselijk lichaam. Deze beginselen vormen "l"ordre public de protection individuelle" die de vrifheid van het individu om over zijn lichaam te beschikken, inperkt. Het ook in het Franse gezondheidsrecht algemeen aanvaarde informed consent beginsel steunt niet zoals in het Duitse of het Nederlandse recht op zelfbeschikking of autonomie. Heers zegt het als volgt: "ce n'est pas ce principe d'autonomie qui tonde la nécessité du consentement ${ }^{\prime \prime}$. En ten overvloede: "l'évolution du droit français des patients ne wa pas pourtant jusqu'à la consécration d'une autonomie à l' américaine

Het hof van beroep van Parijs was klaarblijkelijk overtuigd door het betoog van Heers en heeft de vordering tot schadevergoeding afgewezen in twee arresten van 9 juni 1998. 
Heeft Heers de Franse rechtsopvattingen inzake autonomie wan de patiënt en informed consent op een juiste manier weergegeven? Als dat zo is, dan stelt de geneenschappelijkheid van het Europees medisch dienstverleningstecht minder voor dan men geneigd is te denken op basis van het Europees Verdrag Mensenrechten en Biogeneeskunde. Maar ook (zelfs) het Franse recht blijkt niet te kunnen weerstaan aan zich wijzigende opvattingen. In de toelichting bij artikel 5 van genoemd Verdrag dat op 4 april 1997 mede door Frankrijk werd ondertekend, wordt in verband met informed consent het volgende gezegd: "This rule makes clear patients" autonomy in their relationship with health care professionals and leads to restrain the paternalist approaches which might ignore the wish of the patient". Deze toelichting is wel niet bindend maar er gaat toch een zeker gezag vanuit. Franikrijk keurde ook de aanbeveling 1418 (1999) 1 van de Raad van Europa goed over de bescherming van de rechten van de mens en de waardigheid van terminaal zieken en stervenden, waarin wordt aangedrongen op maatregelen opdat dergelijke patiënten niet tegen hun wil behandeld zouden worden. Wellicht overtuigt dit nog niet iedereen en is meer nodig, van Franse bodem. Welnu, op 27 januari 2000 bracht het alom gerespecteerde Franse Comité Consultatif de Bioéthique een advies uit over euthanasie. De toonzetting van dit advies heeft velen, ook in Frankrijk verrast. Zonder weel omhaal stelt het Comitê wast dat in sommige landen, Denemarken bijwoorbeeld, een patiênt het recht heeft om cen behandeling te weigeren en dat een recente Franse wet betreffende het recht op palliatieve zorg een bepalling bevat met eenzelfde strekking "lorsqu'elle indique que la personne malade peut s'opposer à toute investigation ou thérapeutique". Waarbij sommigen zullen opmerken dat niet duidelijk wordt bepaald dat met dit verzet ook altijd moet worden rekening gehouden... Tegelijk gaan ook in de Franse rechtsleer stemmen op voor een "évolution de la réflexion française": "le respect du patient comme individu suggère aussi que ses choix, ses décisions, soient pris en compte, voire acceptếs, y compris dans des situations d'urgence (...) Cette évolution s"inscrit, au plan international, dans une tendance qui, pour être plus forte dans les pays anglo-saxons n'est pas ignorée par les autres ou par les textes européens ou internationaux".30

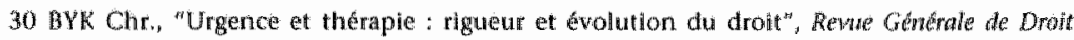
Medical, 2000, nr. $3,18$. 
Een ander voorbeeld waaruit een zekere toenadering blijkt tussen traditioneel zeer uiteenlopende opvattingen is het medisch beroepsgeheim. In Frankrijk leeft nog sterk de mening dat het beroepsgeheim van de arts een absoluut karakter heeft en van openbare orde is. In Duitsland en andere Europese landen daarentegen wordt het medisch beroepsgeheim gerelativeerd in het licht van andere betrokken belangen. Recent rechtsvergelifkend onderzoek heeft het ogenschijnlijk principieel verschil tussen beide benaderingen sterk afgezwakt. Het enige, weliswaar belangrijke onderscheid houdt verband met de vraag of de patiënt de zwijgplicht van zijn arts kan opheffen. Het Franse strafrecht aanvaardt deze mogelijkheid niet. Het Duitse recht wel. Andere relevante verschillen tussen het Franse en het Duitse recht zijn er daarentegen nog nauwelijks. ${ }^{31}$

Het zou niet getuigen van een kritische en wetenschappelijke instelling om het bij deze al bij al impressionistische schets te laten. Alleen een grondig opgezet en gedetailleerd wetenschappelijk onderzoek kan ons in staat stellen de vraag te beantwoorden of het Europees geneeskundig dienstverleningsrecht meer dan een papieren bestaan leidt.

\section{RECHTSVERGELIJKEND ONDERZOEK}

Als methode voor het uitvoeren van dat onderzoek dient zich rechtsvergelijkend onderzoek aan. Maar dat is niet zo vanzelfsprekend. Traditioneel houdt de rechtswergelijking zich bezig met het I.P.R, het handelsrecht, de meer economisch gerichte takken van het burgerlijk recht, het arbeidsrecht en de intellectuele rechten. Meer en meer wint de opvatting veld dat rechtsvergelijking niet tot het handelsverkeer en het traditionele verbintenissenrecht beperkt dient te blijven. Onderwerpen met een grensoverschrijdende betekenis zoals de rechten van de mens, het milieurecht en de bescherming van de consument vormen thans het voorwerp van rechtsvergelijkend onderzoek. Maar ook domeinen die traditioneel niet voorbestemd waren voor de rechtsvergelijking zoals het familierecht en het erfrecht, worden bewerkt. Stilaan wordt aangenomen dat deze rechtstakken toch niet zo cultuurgebonden zijn, als vroeger algemeen werd aangenomen. ${ }^{32}$ Waarom zou dit ook niet voor het gezondheidsrecht

31 MICHALOWSKI S. "Medical confidentiality and medical privilege-a comparison of French

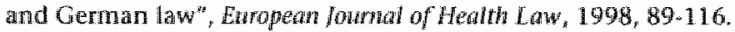

32 PINTENS W., Inleiding tot de rechtsvergeligking, Leuven, Universitaire Pers Leuven, 1998,30 
opgaan, in het bijzonder dan voor de rechten van de patiènt ondermeer omwille van de toegenomen vervlechting met de bescherming van de consument? In de literatuur weerklinkt de roep nar rechtsvergelijkend. onderzoek op dit gebied terecht steeds luider. ${ }^{33}$

De eerlijkheid gebiedt om vast te stellen dat rechtsvergelijking als onderzoeksmethode in het gezondheidsrecht zelden op systematische wijze is toegepast. ${ }^{34} \mathrm{Er}$ zijn natuurlijk de spreekwoordelijke uitzonderingen die de regel bevestigen zoals het opus magnum van Dieter Giesen dat in tussen ook al 12 jaar oud is. ${ }^{35}$ De verklaringen liggen voor de hand zoals de verschillen in taal en rechtscultuur (zeker tussen common law en civil law, waarover verder, maar ook tussen civil law landen - zie hoger). Maar vooral het ontbreken van een motief of een aanleiding om dergelijk rechtswergelijkend onderzoek te verrichten is hiervoor de uiteindelijke verklaring. Waarom, behalve uit louter wetenschappelijke nieuwsgierigheid, zou iemand in het verleden de kembeginselen van het gezondheidsrecht van de lidstaten van de E.U. op een systematische wijze hebben willen vergelijken? De recente erkenning wan een kern aan gemeenschappelijke beginselen in het Europees Verdrag Mensenrechten en Biogeneeskunde, de naar aanleiding van de toegenomen mobiliteit van en informatie- er ervaringenuitwisseling tussen patiënten groeiende behoefte aan gelijke behandeling, een aanzet tot "europeanisering" van de zorgvuldigheidsnorm en het streven naar een Europese identiteit vormen de geschilkte aanleiding om ook het gezondheidsrecht systematisch op de agenda van de rechtsvergelijking te plaatsen.

33 ROSCAM ABBING H.D.C., "Gezondheidsrecht in Europees perspectief" in Liber Amicorum André Prims, Gent, Mys en Breesch, 1995, 299: "rechtswergelijkende studies blijwen nodig. on de verschil- en knelpunten inzichtelijk te maken en om als basis te dienen voor het ontwikkelen van gemeenschappelike regels op specifieke deelterreinen " LEGEMAATE J. "Kroniek wan het gezondheidsrecht" N.J.B., 2000, 557 : "Het belang van rechtswergelijking. neemt toe evenals het belang van uitwlsseling van nationale ervaringen".

34 dite ook GRUBR A., "Comparative Luropean Heath Law" Eutopean Joumal of Health Law, 1997,293: "as yet, the closer geagraphic connections between continental Lurope and fingland have surprisingly lead to little sustamed comparative study in the area of health $\operatorname{law}^{t r}$.

35 GIHaSilN D. Intemarianal Medical Malpractice Law, Springer, Tubingen, 1988. Zie voor wat de rechten van de patternt betreft, LEENEN H.J., GEVERS J.K.M. en PINET G., The rights of patievts in Europe, a comparative study, Kluwer, Deventer, 1993. Op deelgebieden van de rechten van de patient is al wel heel wat rechtswergelijkend onderzoek werricht. Zle bijoor.w beeld het in wotnoot 31 vermelde artikel en GIESEN I., Bewtishastverdeling bij beroepsanspraketifhtheld, Dewernter, Tjeenk Willink, 1999 in thet bijzonder hoofdstuk 2 in verband met de anspralkelikheid voor informatieverzuim. 
Geneeskundig dienstverleningsrecht is in de meeste lidstaten van de E.U. bij witstek rechtersrecht. Dat de rechten en plichten van dienstverlener en -ontvanger bij wet zijn geregeld is eerder nog uitzondering dan regel. Slechts in vier lidstaten van de E.U. bestaat een wettelijke regeling van de rechten van de patiënt. In plaats van generaliserende uitspraken te verkondigen over buitenlands recht op basis van wat in wetgeving en deontologische codes is geregeld, zal door een gedetailleerde analyse van wetgeving (indien die er is), rechtspraak en rechtsleer worden gepoogd om te komen tot cen realistische inschatting van de mate van aanvaarding van de harde kern van beginselen vervat in het Europees geneeskundig dienstverleningsrecht. Dit vergt om te beginnen een nauwkeurig begrip van de inhoud van deze beginselen die vaak kernachtig zijn uitgedrukt en voor meer dan één interpretatie in aanmerking komen. Hierbij kunnen we ons ondermeer oriënteren op de Nederlandse Wet op de geneeskundige behandelingsovereenkomst waarvan Hondius reeds in 1995 heeft beweerd dat ze "een goede keuze is geweest, die gerust aan andere landen tot woorbeeld mag strekken. Bij de voorbereiding van een Europese richtlijn kan de WGBO goede diensten bewijzen" ${ }^{36}$ Ook de resultaten van de recent uitgevoerde evaluatie van bepaalde onderdelen van de WGBO kunnen ons hierbij behulpzaam zijn. ${ }^{37}$

Een moeilijk te beantwoorden vraag is welke landen in het rechtsvergelijkend onderzoek zullen worden betrokken. Ideaal zou zijn dat alle 15 lidstaten van de Unie in het onderzoek worden opgenomen maar om allerlei redenen (taal, tijd, geld vooral) is dat (voorlopig) niet haalbaar. Landen die er zeker bijhoren zijn: België, Duitsland, Frankrijk, Luxemburg en Nederland. De talen vormen geen onoverkomelijk probleem. Qua rechtscultuur zijn deze vijf landen voldoende vergelijkbaar terwijl juist in laet vrij recente domein dat het gezondheidsrecht is zodanige verschillen zijn geslopen - er werden al meerdere voorbeelden van gegeven - dat zo'n vergelijking ook boeiend is en veel leerrijk onderzoeksmateriaal zal opleveren. De zorg- en verzekeringsstelsels van deze vijf landen leveren eenzelfde beeld op als de rechtscultuur. Allemaal voortgekomen uit het Bismarck-model, hebben ze zich tot soms zeer verschillende systemen ontwikkeld. Interessant is ook nog dat België en Duitsland het Europees

36 HONDIUS E., "De privaatfechtelijke positie van de pathent in Europees perspectief", TPR, $1995,31$.

37 DUTE J.CJ. ea, De evaluate van de WGBO, Den Haag ZorgOnderzoek Nederland, 2000, Heeks evaluate regelgeving : ded 3,467 . 
Verdrag Mensenrechten en Biogeneesikunde niet ondertekenden terwill Franrijk, Luxemburg en Nederland dat wel deden. Met de twee eerste hebben we te maken met federale staten terwijl de drie andere eenheidsstaten kunneni worden gemoemd. Geneeskundig dienstverleningsrecht is in Belgie en Duitsland een bevoegdheid van zowel de federatie als de deelstaten en een inzicht in de mogelijkheden en moeilijkheden van die bevoegdheidswerdeling kan van belang zijn bij het verder uittekenen van het Europees medisch dienstverleningsrecht.

Meegenomen is ook dat deze landen als het ware de voortuin van Maastricht vormen.. Vooral voor het onderzoek naar de law in action is dat interessant. Het bevragen in een aantal ziekenhuizen in de Euregio rond Maastricht van dienstverleners en -ontvangers naar hun meningen en praktijken in verband met de beginselen van het geneeskundig dienstverleningsrecht zou een belangrijk onderdeel moeten uitmaken van dat onderzoek. Ik bekijk Maastricht als een proeftuin voor een grootschalig onderzoek naar het Europees geneeskundig dienstverleningsrecht. In het Belgische Sankt-Vith (dat tot 1919 deel uitmaakte van Duitsland) heb ik mi|n proefbuis gevonden: de Klinik St.Joset, een algemeen ziekenhuis met nog geen 150 bedden waar artsen werken die zijn opgeleid in België, Duitsland en Frankrijk en waarin, omwille van de ligging, ook patiënten uit het Groot Hertogdom Luxemburg worden opgenomen.

Het zou moeilijk te verantwoorden zijn in het geheel geen van de Scandinavische landen in het onderzoek te betrekken. Deze landen zijn de pioniers inzake een wettelijke bescherming van de rechten van de patiënt en de vergoeding van schade ten gevolge van medische ongevallen. Hier stelt zich wel het probleem van de taal. Daarom zal moeten worden uitgekeken naar betrouwbare alternatieve oplossingen zoals vragenlijsten en expertengesprekken. ${ }^{38}$ Hetzelfde geldt voor de Zuideuropese landen waarvan er eveneens op zijn minst één in het onderzoek zal worden opgenomen.

Een delikate vraag is of ook Engeland (niet het Verenigd Koninkrijk alszodanig wegens te grote verschillen tussen Engels, Schots en Welsh recht) wan meetaf aan wordt meegenomen in het onderzoek. De taal levert geen probleem op; tijdschriften als de Medical Law Review en de Europear Journal of Health Law en klassieke handboeken als Medical Law van lan Kennedy en Andrew Grubb hebben het Engelse medisch recht in belang- 
rijke mate ontsloten voor de continentale jurist. $\mathbb{k}$ voel er dus veel voor om de uitnodigende hand van Grubb te grijpen. Hij schrijft: "The future will be different. Strides must be made to adopt the comparative approach to health law. The rich stream of health law in the European states makes it essential for lawryers to learn from their neighbours" 39

Daartegenover staat dat de verschillen tussen civil law en common law groot blijven. In zijn recente oratie heeft Jan Smits een aantal ervan nog eens goed in de verf gezet aan de hand van een analyse van de verplichting om een persoon in groot gevaar te helpen. ${ }^{40}$ Die analyse brengt hem tot het besluit dat de functie van het recht in civil law en common law principieel verschilt: "in the civil law, duties to rescue are not seen as mere moral duties, but as civic duties (..) This corresponds with looking at the law's function as promoting the good; laws essentially provide a moral compass that points society its proper direction". ${ }^{41}$ In de common law "the function of the law just is not to promote the good, but to guarantee each and everyone a private moral sphere that is free from unnecessary human interference". Dat verschil is zoals gezegd principieel: "to look at the law as essentially there to promote the good, is definitely not the same as to look at it as guaranteeing each and everyone a private moral sphere" ${ }^{42}$ Smits bekijkt om deze reden het zoeken naar gemeenschappelijke Europese privaatrechtelijke beginselen erg sceptisch hetgeen tot uiting komt in de ondertitel van zijn oratie: "On the perils of principles without a programme and a programme for the future". Als een gemeenschappelijke Europese "moraliteit" ontbreekt, heeft het geen zin te zoeken naar uniforme beginselen "without simultaneously changing that morality". Maar " to make morality part of the common law requires a shift in mentality of the English people as a whole, which involves much more than a change of the law only". ${ }^{43}$

Of Smits' boodschap in zijn algemeenheid juist is of niet, kan ik niet beoordelen. Wel voel ik veel voor zijn benadering: het heeft geen zin naar uniforme beginselen te zoeken als dat alleen maar kan door de nationale rechtsstelsels te herleiden tot een schim van zichzelf. Ook heeft het geen

39 GRUBB A., O.G,..

40 SMITS J. The Good Samaritan in European Prikate Law, Deventer, Kuwer, 2000

41 SMITS J, o.c. 33 .

42 In die zin ook, VAEL L., "Altruïsme wor recht gekomen". TPR, 1999, nr. $1,79.114$

43 SMITS J, o.c, 40 . 
zin zomaar op zoek te gaan naar uniforme beginselen zonder een visie op de toekomst, zonder programma.

lk keer terug naar de verschillen tussen continentaal en Engels recht. In het gezondheidsrecht zijn die soms verrassend groot. Zo heeft het Engelse recht - en dit tot verbazing van menig continentaal jurist die al wat Angelsaksisch is over dezelfde kam pleegt te scheren - de informed consent doctrine nog niet aanvaard. ${ }^{44}$ Anders dan in het Duitse en het Nederlandse recht geldt als standaard woor de informatieplicht wat een meerderheid van redelijk handelende artsen in een soortgelijk geval zou hebben gedaan (de zgn. Bolam-test). Wat de betrokken patiënt ervan denkt is van geen tel : "what the doctor decides you should know". 45 Weer is de vraag: hoe principleel is dat verschil? Dat het Engelse recht de informed consent doctrine niet heeft erkend, is geen gevolg van de common law alszodanig. In Australië, Canada en in de VS - bakermat van de doctrine - is zij springlevend. Het Engelse recht is dus niet immuun voor de doctrine en reeds zijn er aanwijzingen dat ook in Engeland een verandering op til is: " while the doctrine as articulated elsewhere is unlikely to be adopted per se, the principles it embodies are gradually becoming the standard by which medical practice is measured by British courts". ${ }^{46}$ Merkwaardig is dat de British Medical Association de stap naar aanvaarding van de doctrine trouwens all heeft gezet. In dat verband rijst ook de vraag of de doctrine beter af is in onderimeer het Belgische recht. Wat wordt precies bedoeld met de bewering dat het Engelse recht de doctrine nog niet kent? Als dit betekent dat de arts beslist of de patiënt voldoende informatie heeft gehad om zelf uit te maken of hij de behandeling wenst te ondergaan ${ }^{47}$ dan is de doctrine in thet Belgische recht evenmin al van toepassing. In beide opzichten moeten de op het eerste gezicht grote verschillen tussen civil law en common law inzake informed consent zeker niet worden overdreven.

44 in die zin HONDIUS $\mathrm{H}_{\text {; }}$ "Medische ansprakelilkheid in Engeland", NJB, 1993, 1004; recent ook nog MURRAY E ,The future of Informed Consent in British Common Law", Europearn Joumal of Health liaw, 1999, 235-248 en Lord IRVINE OE LAIRG, "The patient, the doctor, thelr lawyers and the judges; rights and duties", Medical Law Review, 1999,255-268; BRAZIER

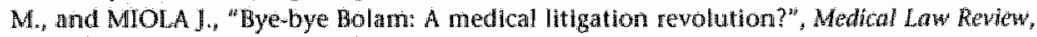
$2000,84-114$; OILSEN 1, 0.6, 37-39,

45 HEWSON B." "Why the Human Rights Act matters to doctors", British Medical houmal, 2000, 780.781.

46. MURRAY E., $0_{0} x, 246$.

47 In die zin GIESEN $1,0,6,38$. 
Dat neemt niet weg dat nog belangrijke punten van onderscheid bestaan tussen continentaal en Engels gezondheidsrecht: bijvoorbeeld het ontbreken van een strafrechtelijke bescherming van het medisch beroepsgeheim in het Engelse recht. Of de heel andere manier van bescherming van wilsonbekwame patiënten. Als de will van zo'n patie̊nt niet gekend is, dan handelt de Engelse arts als een soort van zalkwaannemer; de verwanten staan er bij te kijken. Op het continent is de trend naar plaatsvervangende toestemming door formele of informele vertegenwoordigers veel dominanter aanwezig.

Behalve een aparte rechtscultuur heeft Engeland ook een andere zorgcultuur: de National Health Service stamt uit de Beveridge-traditie. Er zijn weinig instituten die zo typisch Brits zijn als die National Health Service. Als exportproduct naar het continent is het vandaag totaal ongeschikt.

Alles bij elkaar genomen, kan het Engelse recht niet buiten het rechtsvergelijkend onderzoek worden gelaten. Enerzijds omdat het Engelse recht heel wat voorbeelden bevat waaruit blijkt dat de rechten van de patiënt op een andere wijze kunnen worden beschermd dan wij op het continent gewend zijn. Anderzijds omdat kan worden vastgesteld dat civil law en common law op een aantal punten naar elkaar toe groelen. De recent in Engeland in werking getreden Human Rights $\mathrm{Act}^{48}$ zal deze ontwikkeling nog stimuleren.

\section{BESLUIT EN DANKWOORD}

Dames en heren, ik kom tot een besluit. Patiënt zijn in Europa is vandaag niet vanzelfsprekend. We moeten niet wachten tot het zover is maar nu al het voortouw nemen om ontwikkelingen te stimuleren die een grotere gelijkheid in de bescherming van de rechten van de patiënt binnen Europa kunnen verwezenlijken. Dat kan slechts op een verantwoorde wijze vanuit een klaar inzicht in de overeenkomsten en verschillen die er nu bestaan tussen de lidstaten. Om dat inzicht verder te verdiepen en uit te dragen, verkeer $\mathrm{lk}$ als hoogleraar internationaal gezondheidsrecht aan de Universiteit Maastricht in een benijdenswaardige positie.

Want ik doe dat vanzelfsprekend niet alleen. Mijn benoeming is in de eerste plaats het resultaat van het doorzettingsvermogen van Frans van Wijmen met wie ik all bijna twee decennia in wisselende configuraties

48 zine noot 45 . 
samenwerk. Frans, samen deden we al meerdere vergelijkende onderzoeken ondermeer op het gebied van waarden en normen woor de werpleging en de verzorging. ${ }^{49}$ Ik wind het een woorrecht dat ik nu van dichtbij kan delen in de grote creativiteit die je in Maastricht ontplooit, niet alleen in het gezondheidsrecht maar ook ver daarbuiten. Jos Dute heeft woor mij letterlijk plaats geruimd in zijn werkkamer. Jos, de twee rechtsvergelijkende onderzoeken die we sedert enkele weken samen met Metro uitvoeren en begeleiden, houden niet toevallig verband met de rechtsbescherming van patienten in Europees perspectief. Ik ben je dankbaar dat we al zo snel concrete resultaten hebben geboekt in het aantrekken van onderzoeksmiddelen op dit terrein en ik beschouw het als een goed woorteken voor de nabije toekomst. I $k$ heb er ook vertrouwen in dat de samenwerking met alle andere medewerkers van de vakgroep vlot zal verlopen. Aan mijn eerste contacten met Michael Faure en Ruud ter Meulen bewaar ik vooornamelijk stimulerende herinneringen.

Mijn dank gaat verder uit naar de decaan van de faculteit der gezondheidswetenschappen en naar de leden van het college van bestuur wan de Universiteit van Maastricht. Ik beschouw het als een privilege te mogen werken aan deze Universiteit waarvan de naam overal ter wereld verbonden is met de verderschrijdende unificatie van Europa.

Tot slot wil ik mijn vrouw en mijn kinderen bedanken voor al wat ze voor mij betekenen.

Geachte aanwezigen, $i k$ dank $u$ woor ww aandacht.

49 DE JONG I.A. W. , a. Warden en wormen woor de vergleging en verzorging vanut ethisch en juri-

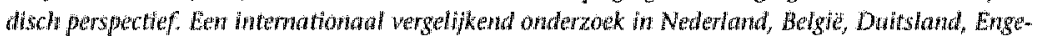
laind en Frankrijk, Antwerpen, Intersentia Rechtswetenschappen, Reeks "Recht en Geneeskunde": 1999. 